\title{
The effect of quartet play on knowledge, attitude, and hand washing practices in school-aged children
}

\author{
Ria Kustiani ${ }^{1}$ Umi Solikhah ${ }^{2}$ \\ ${ }^{\mathbf{1 , 2}}$ Faculty of Health Science, Muhammadiyah University of Purwokerto
}

\begin{tabular}{l}
\hline ARTICLE INFO \\
\hline Article history: \\
Received: August 9, 2020 \\
Revised: August 20, 2020 \\
Accepted: August 30, 2020 \\
\hline
\end{tabular}

\section{Keywords:}

Hand washing, play therapy, Quartet

\begin{abstract}
Hand washing compliance is still relatively low. Efforts are needed to improve the quality of health and welfare, one of which is through education on the habit of hand washing with soap (HWWS). The objective of the study was to investigate the effect of play therapy using quartet media on knowledge, attitudes and practices of hand washing in school-aged children aged 9-12 years. This study employed a quasi-experimental one group pre-test-post-test method conducted at Banyumas Hospital. The sampling technique used was simple random sampling with a sample of 55 respondents. The research instruments occupied were a knowledge questionnaire, an attitude questionnaire, and an observation sheet for the practice of washing hands with soap. Data were analysed using the Wilcoxon test. The results revealed that knowledge, attitudes, and practices of washing hands with soap increased after being given play therapy using a quartet. The Wilcoxon test result obtained was a significance value (p) on the effect of playing therapy using quartet media, namely knowledge $\mathrm{p}=0.000$, attitude $\mathrm{p}=0.000$, and practice $\mathrm{p}=0.000$. Play therapy using quartet media has a significant influence on knowledge, attitudes, and practices of washing hands with soap.
\end{abstract}

This work is licensed under a Creative Commons Attribution 4.0 International License.

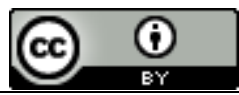

\section{Corresponding Author:}

Ria Kustiani, Umi Solikhah

Health Science Faculty

Muhammadiyah University of Purwokerto.

Email: nadifria@gamil.com, umisolihah@ump.ac.id

\section{INTRODUCTION}

Sustainable Development Goals (SDGs) is a global movement launched by the United Nations Development Program to improve the quality of life for the world's people through 17 main pillars. One of the most important pillars of the SDGs is the third pillar, namely health and welfare. One way to improve the quality of health and well-being is by disseminating the Clean and Healthy Life Behavior (CHLB) program through education on the habit of hand washing with soap (HWWS). Through HWWS, the germs / bacteria that cause infection are cut off, life becomes healthier so that the quality of life increases. HWWS has been recommended as an important way to protect individuals from diseases such as foodborne parasitic infections. A systematic review of non-experimental and experimental studies related to hand washing has supported the importance of hand washing as a relevant infection control measure. [1]

The proportion of the population aged more than 10 (ten) years old who wash their hands properly and correctly in Indonesia raised from $23.2 \%$ in 2007 to $47.0 \%$ in 2013. Furthermore, according to basic health research in 2013 in Central Java Province, the correct behavior of hand washing of the population $\geq 10$ years showed a decline from 2007 to 2013 with the results in 2007 there was $56.8 \%$ decreased until in 2013 there was $49.5 \%$. In Semarang City, on the other hand, the proportion of correct hand washing behavior of population $\geq 10$ years according to the 2013 basic health research result declined from 2007 to 2013, in 2007 there was $47.1 \%$ reducing to $45.5 \%$ in 2013. [2]

According to a study conducted [3] at a hospital in China, the patients in that hospital most of the patients (72.2\%) reported that they did not know about hand hygiene knowledge or knew little about it. Less than half $(47.4 \%)$ of the patients had previously received hand hygiene education from both a health worker 
(35.6\%) and television (28.5\%). $75.8 \%$ of patients washed their hands after using the toilet, but only $11 \%$ of them washed their hands before taking the medicine. In addition, the results of the study also revealed that only $11.9 \%$ of patients washed their hands before interacting with visitors and $13.2 \%$ washed their hands after visitors left. In addition, in this study it was found that, although patients had a positive attitude towards hand hygiene, their knowledge was insufficient because of the unavailability of hand hygiene education in daily life or after discharge from the hospital. They do not know when and how to wash their hands in their daily life. Children at school age can receive information, knowledge, and instructions that they can predict [4] .Handwashing with soap counseling can be done using the play method, because by playing the learning process is more effective and fun so it is suitable for use in children [5]. According to the National Association for the Education of Young Children (NAEYC) ), play is the main learning tool for children. Play will satisfy the demands of the development of motor, cognitive, language, social and life values. Play therapy is an activity in which children perform or practice skills, give expression to creative thinking, prepare themselves to play a role, and behave in an adult manner [6].

The quartet card game was chosen because it was fun and familiar to the respondent, the material in the quartet card is presented in the form of a picture equipped with information so that it has a special attraction for children to learn it even though the game requires intelligence, assertiveness and dexterity to learn ideas or basic concepts that need to be memorized. This study was aimed to investigate the effect of play therapy using quartet media on knowledge, attitudes and practice of hand washing in school-aged children aged 9-12 years.

\section{RESEARCH METHOD}

The type of this research was a quantitative research with a quasy experimental research design with one group pretest posttest design, and the analytical test employed was the Wilcoxon Test. The sampling technique used was simple random sampling with a sample size of 55 respondents.

\section{RESULT AND DISCUSSIONS}

Table 1. The Characteristics of the Respondents Based on Gender and Age $(n=55)$

\begin{tabular}{lc}
\hline \multicolumn{1}{c}{ Variable } & Result \\
\hline Gender & $30(54.5 \%)$ \\
Male & $25(45.5 \%)$ \\
Female & \\
Age (in year) & $10.53 \pm 1.12$ \\
Mean \pm SD & $9-12$ \\
Min - Max &
\end{tabular}

Table 1 shows that of the 55 respondents studied, $54.5 \%$ were male and $45.5 \%$ were female. The mean age of the respondents was 10.53 years with a standard deviation of 1.12 , minimum age 9 years and maximum age 12 years.

Table 2. The Description of Knowledge, Attitudes, and Practices of Hand Washing with Soap before and after Play Therapy

\begin{tabular}{lcc}
\hline Variable & Before & After \\
\hline Knowledge & & \\
Mean \pm SD & $5.67 \pm 0.982$ & $6.93 \pm 0.262$ \\
Min - Max & $3-7$ & $6-7$ \\
Attitude & & \\
Mean \pm SD & $34.11 \pm 4.387$ & $37.87 \pm 1.711$ \\
Min - Max & $16-40$ & $34-40$ \\
Practice & & \\
Mean \pm SD & $2.22 \pm 1.34$ & $7.02 \pm 0.135$ \\
Min - Max & $2-8$ & $7-8$ \\
\hline
\end{tabular}

Based on table 2, it shows that of the 55 respondents studied, the pre-test mean score of knowledge of washing hands with soap was 5.67 with a standard deviation of 0.982 , a minimum score of 3 and a maximum score of 7. After playing therapy was carried out using a quartet, the mean score of knowledge to be 6.93 with a standard deviation of 0.262 , a minimum score of 6 and a maximum score of 7 . This illustrates the importance of continuous health education efforts to increase knowledge about washing hands with soap. Information received through print, electronic, education / counselling, books and so on will increase a person's knowledge so that he will be able to improve or change his behaviour for the better. A person's knowledge is also influenced by experiences gained from before and through formal education. 
Based on the results of the above research, the researchers argue that the knowledge of washing hands with soap after playing therapy has increased. Good knowledge about washing hands with soap must be based on health education. Health education not only provides facts about risks and actions that worsen health, but this knowledge can also lead a person to experience behaviour change [7]. Attitude is a reaction or response that is still closed from a person to a stimulus or object [8]. The findings of this study can be influenced by several factors in the formation of attitudes, including personal experience, culture, mass media, educational institutions and religious institutions, as well as emotional factors in individuals.

Researchers argue that play therapy can improve the respondent's hand washing attitude. An increase in the value of attitudes about washing hands with soap after play therapy shows that health education through play therapy has an effect and has a positive attitude to wash hands in everyday life [9]. There is very little pretest practice. The results of the pre-test score can be influenced by several factors, including a lack of knowledge and a lack of care for health. Researchers argue that play therapy can improve the respondent's hand washing attitude. The role of health promotion which is a process to make individuals and communities able to improve and control the factors that affect their health is required so that there is an increase in the health of individuals and communities [10].

Table 3. The Effect of Play Therapy Using Quartet Media on Knowledge, Attitudes, and Practices of Hand Washing with Soap $(n=55)$

\begin{tabular}{lccc}
\hline Variable & Before & After & p-value \\
\hline Knowledge & & & 0.000 \\
Mean \pm SD & $5.67 \pm 0.982$ & $6.93 \pm 0.262$ & \\
Min - Max & $3-7$ & $6-7$ & \\
Attitude & & & 0.000 \\
Mean \pm SD & $34.11 \pm 4.387$ & $37.87 \pm 1.711$ & \\
Min - Max & $16-40$ & $34-40$ & 0.000 \\
Practice & & & \\
Mean \pm SD & $2.22 \pm 1.34$ & $7.02 \pm 0.135$ & \\
Min - Max & $2-8$ & $7-8$ & \\
\hline
\end{tabular}

Table 3 shows the statistical test results of the mean difference in knowledge, attitudes, and hand washing practices before and after the intervention with $\mathrm{p}$ value obtained was 0.000 .

\subsection{Knowledge}

The difference in knowledge of washing hands with soap was significant between before and after playing therapy using quartet media, with a mean of 6.93, a minimum score of 6 , a maximum score of 7 and a value of $p=0.000$. Several studies have shown that stimulation of learning through play can improve cognitive, attitude and behaviour. The results of this study are also supported by previous research conducted [11] with the title 'the effect of video media and games of snakes and ladders in increasing children's behaviour regarding washing hands with soap at Dian Ekawati Kindergarten'. In her research, it was explained that there were differences in children's behaviour before and after being given health education treatment, snake and ladder media were more influential in increasing children's knowledge and attitudes about HWWS compared to video, because snakes and ladders provided more stimulation to children and in accordance with children's wishes, namely playing. In providing health education to school-age children, the most important thing that must be considered is the use of media that are easily accepted by children. Picture card media is suitable for schoolage children because it is easy to remember thus it is very helpful [12].

\subsection{Attitude}

The results revealed that there were significant differences in the attitude of washing hands with soap between before and after playing therapy using quartet media, with a value of $p=0.000$. Change can only occur in response to something new, evocative and fun. Appropriate behaviour development is given as early as possible because in addition to children having high curiosity, they also have good memory and are easy to adopt new behaviours [13]. In teaching hand washing with soap to school-age children, the right method and media are needed. The quartet card game is one of the games that can be used in education, because in addition to being fun and familiar to children, the material in the quartet card is presented in the form of a picture equipped with information so that it has its own appeal for children to learn it even though in the game. It requires intelligence, assertiveness and dexterity to learn and understand basic ideas or concepts that need to be memorized. Based on research conducted [14], health education using quartet cards can improve children's knowledge and attitudes regarding oral and dental care. 


\subsection{Practice}

The results depicted that that there were significant differences in the practice of washing hands with soap between before and after playing therapy using quartet media, with a value of $p=0.000$. The results of another study conducted [15] also revealed that the respondent's hand washing skills after playing therapy showed $70.4 \%$ had good hand washing skills and $29.6 \%$ had sufficient hand washing skills. The results proved that the $p<0.001$. There is an effect of SCL (Snake, Cards, and Ladders) playing therapy on the handwashing skills of grade I and II students at Pakusari II Elementary School, Jember Regency. Playing games with educational learning media, children do not feel that they are learning. Fun activities can also actively increase brain cells, can stimulate children's thinking, including the ability to concentrate and solve problems [16].

\section{CONCLUSION}

There are differences in knowledge, attitudes, and practices of washing hands with soap after playing therapy using quartet media for school-aged patients at Banyumas Hospital.

\section{REFERENCES}

[1] S. Chang, "Correlates of School Children's Hand Washing: A Study in Tibetan Primary Schools," International Journal of Environmental Research and Public Health, vol. 16, p. 3217, 2019.

[2] D. RI, ““HCTPS 2013: Tanganku Bersih Hidupku Sehat”, 2013,” Depkes RI, 2013. [Online]. Available: http://www.depkes.go.id. [Acesso em 08 Agustus 2019].

[3] L. Yunxia, "Knowledge and practice of hand hygiene among hospitalized patients in a tertiary general hospital in china and their attitudes: a-cross sectional survey," BMJ open, vol. 9, 2019.

[4] U. Solikhah, S. Nurjannah e Supriyadi, "Therapeutic Intervention of Respiratory Tract Cases in Children," Indian journal of public health research and development, vol. 10, nº9, pp. 1916-1921, 2019.

[5] Purnamasari, Berty, ““"Efektifitas Penyuluhan dengan Kartu Kuartet Berbasis Multimedia terhadap Pengetahuan Kesehatan Gigi dan Mulut pada Anak Usia 8-10 Tahun,” [Skripsi], Jember, Digital Repository Universitas Jember, 2015.

[6] Adriana, Dian, Tumbuh Kembang dan Terapi Bermain Pada Anak., Jakarta: Salemba Medika, 2013.

[7] United Nations Children's , "Fund, Water, Sanitation and Hygiene (WASH) in School, USA," UNICEF, USA, 2012.

[8] S. Notoatmodjo, Promosi Kesehatan dan Perilaku Kesehatan, Jakarta: Rineka Cipta, 2012.

[9] Hasanah, T. Meilana, Majid, Y. Abdul, Tirtayan, "Kartu Bergambar Meningkatkan Penegtahuan, Sikap, dan Prosedur Mencuci Tangan Anak Kelas 5 SD di SD Muhammadiyah 14 Balayudha Palembang Tahun 2019," Healthcare Nursing Journal Fakultas Ilmu Kesehatan UMTAS, vol. 2, $\mathrm{n}^{\circ}$ 01, 2019..

[10] Rizal, Achmad, J. Agus, "Pengaruh Intervensi Promosi Kesehatan Terhadap Pengetahuan dan Sikap Cuci Tangan Pakai Sabun pada mahasiswa," Jurnal Ilmiah Ilmu Kesehatan: Wawasan Kesehatan, vol. 6, no 1, pp. 69-74, 2019.

[11] Prayogi, "Pengaruh Media Vidio dan permainan Ular Tangga dalam Peningkatan Perilaku Anak Mengenai Cuci Tangan Pakai Sabun di TK Dian Ekawati,” Universitas Sumatra Utara, Medan, 2017.

[12] Angreany, Femmy, "Keefektifan Media Pembelajaran Flashcard dalam Keterampilan Menulis Karangan Sederhana Bahasa Jerman Siswa Kelas XI IPA SMA Negeri 9 Makasar," Jurnal Pendidikan Bahasa Asing, vol. 1, n 2, 2017.

[13] Amareta, D. Indah, Ardiano, E. Tri, "Peningkatan Praktik Cuci Tangan Pakai Sabun pada Anak Usia Sekolah dengan Metode Emo Demo,” Jurnal Kesehatan Lingkungan, vol. 9, n 2, pp. 88-92, 2017.

[14] Nurlaila, "Pengaruh Permainan Kartu Kuartet terhadap Pengetahuan, Perilaku dan Sikap Anak-anak tentang Perawatan Gigi dan Kesehatan Mulut," Jurnal Keperawatan Soedirman, vol. 13, n 1, 2018.

[15] Azizah, Nurul, "Pengaruh Terapi Bermain SCL (Snake, Cards, and Leaders) terhadap Keterampilan Cuci Tangan Siswa Kelas I dan II di SDN Pakusari II Kabupaten Jember," e-Jurnal Pustaka, vol. 3, $n^{\circ} 2,2015$.

[16] Hikmah, Ema, "Pengaruh Terapi Bermain Puzzle Terhadap Sikap dan Keterampilan Mencuci Tangan Pada Anak di SD Taman Sukaria I Kota Tangerang," Media Informasi Kesehatan, vol. 6, nº 1, pp. 77-88, 2019. 